\section{CORROSION PROCESSES ON WEATHERING STEEL RAILWAY BRIDGE IN PRAGUE}

Viktor Urban*, Vit Krivy, Vojtech Buchta

VSB - Technical University of Ostrava, Faculty of Civil Engineering, Department of Building Structures, 17. listopadu 15/2172, Ostrava Poruba 708 33, Czech Republic
Article history

Received

10 June 2015

Received in revised form

11 September 2015

Accepted

12 December 2015

*Corresponding author viktor.urban@vsb.cz

\section{Graphical abstract}

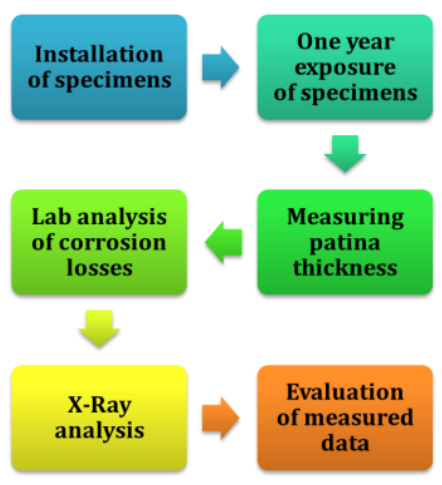

\begin{abstract}
This contribution deals with experimental corrosion tests carried out on the weathering steel railway bridge in Prague. The basic specific property of the weathering steel is an ability to create in favourable environment a protective patina layer on its surface. Since 1968 weathering steel is used under the name "Atmofix" in the Czech Republic and can be used as a standard structural material without any corrosion protection. The weathering steel Atmofix is mostly used for bridge structures and lattice transmission towers. Some of these constructions built in the Czech Republic have been assessed and inspected in the last few years. Authors of this paper developed a new methodology of nondestructive experimental testing of corrosion processes. Testing specimens are installed on typical surfaces of steel bridges in such a way to simulate real conditions of the examined surface. This paper describes results of corrosion tests (thickness of corrosion products, corrosion losses and X-Ray analysis) after one-year exposure, correlation factor and dependence of location.
\end{abstract}

Keywords: Weathering steel, bridges, corrosion, corrosion losses, corrosion test, experimental testing

(C) 2016 Penerbit UTM Press. All rights reserved

\subsection{INTRODUCTION}

This paper deals with experimental corrosion test on the 3-span composite weathering steel and concrete bridge in Prague. The girder bridge is situated in the capital city of the Czech Republic in corrosion aggressiveness $\mathrm{C} 2$. The average annual air temperature achieves $9.8{ }^{\circ} \mathrm{C}$ in observed area. The bridge was built in 1981 and the assembling completed in 1983. The steel construction is designed from low-alloy weathering steel Corten B. The supporting construction is created by four main girders designed as welded I-sections. The girders in each of the three spans are designed as $20 \mathrm{~m}$ long simply supported beams, see Figure 1. The main girders are connected to each other by crossbeams. The railway track is stored in a gravel railroad bed. Total weight of the steel structure is 155 tons.

The weathering steel is able to protect its surface with a thin layer of corrosion product called patina.
This protective layer covers the surface of the whole structure, protects against external climatic influences and the construction resists completely without an anticorrosion coating $[1,2,3,4]$.

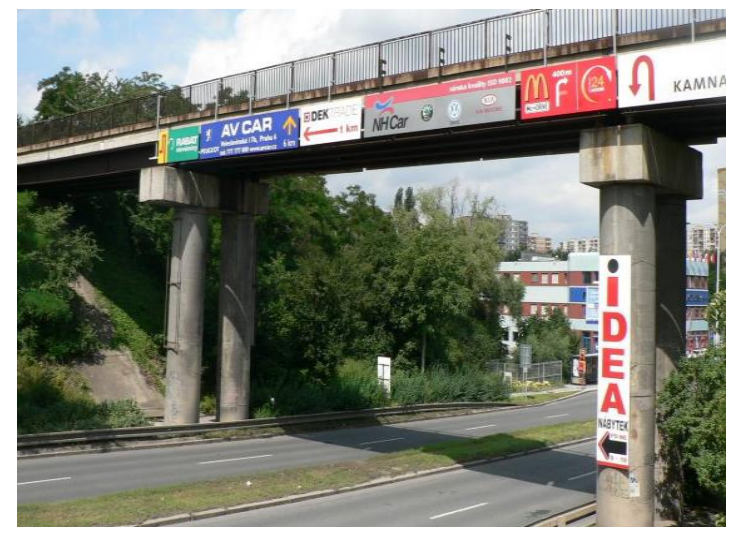

Figure 1 Side view on the railway bridge in Prague 


\subsection{SPECIMENS FOR TESTING}

The protective patina layer slowdowns the corrosion rate $[5,6]$. The effects of the expected corrosion losses are typically eliminated by corrosion allowances which are added to the thickness of the structural element calculated in static analyses [7, 8]. The quantity of corrosion losses depends on the position and location of the surface in the structure [9]. The specimens are installed on typical surfaces of the structure. The specimens are flat panels made of steel S355J2WP with a nominal size $150 \times 100 \mathrm{~mm}$ and with thickness $1.5 \mathrm{~mm}$ [10]. The specimens are attached to the structure with a special anchoring device [11], see Figure 2. Three specimens are installed on typical surfaces of the structure. The specimens will be withdrawn after one, three and ten years of exposition.

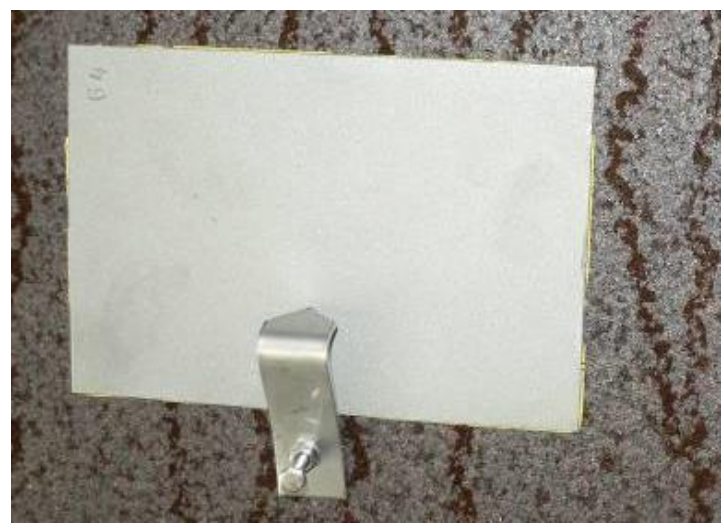

Figure 2 Specimens attached by anchoring device

\subsection{SELECTED SURFACES}

The first three specimens of surface S1 are installed on the external web of the external (northern) main girder close to the western abutment, see Figure 3. This surface is not affected by leaking from drainage system even by the proximity of upper or bottom flanges. The patina development is typical for the whole surface - compact, uniform and visually favourable.

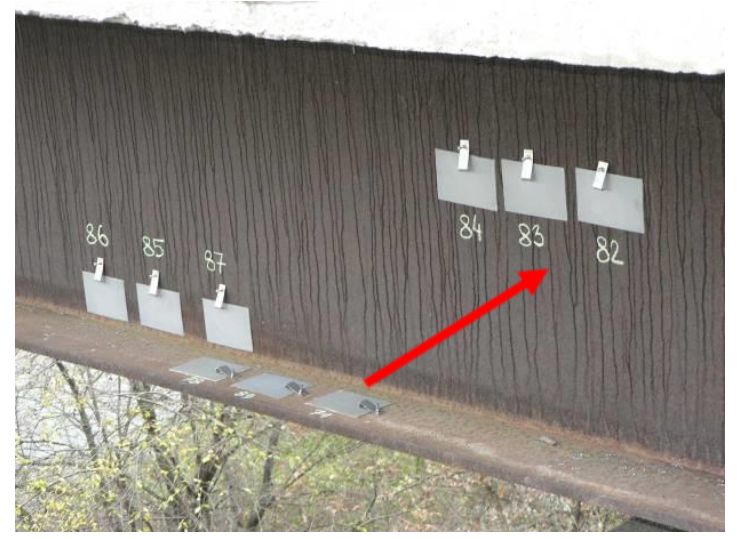

Figure 3 Northern external main girder (external web)
The specimens of surface $\$ 2$ are installed on the external web of external (southern) main girder close to the western abutment. This surface is not affected by leaking from drainage system even by the proximity of upper or bottom flange, see Figure 4 .

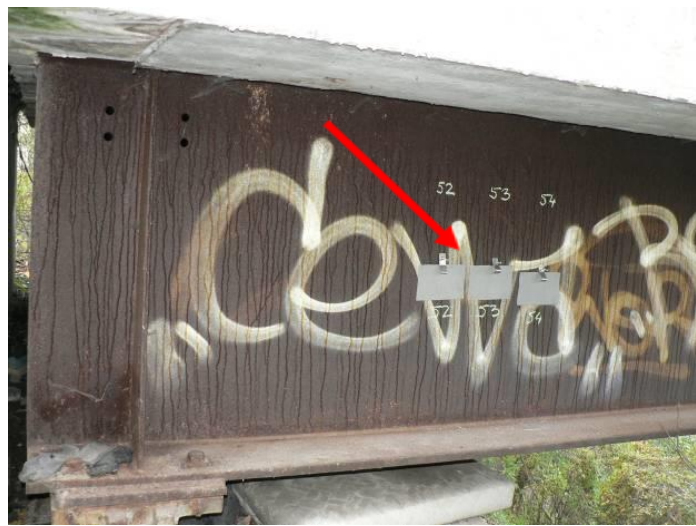

Figure 4 Southern external main girder (external web)

The surface is typical for the whole length of the main girder. Patina layer is uniform, compact and visually favourable. The strips resulting from flowing water on the specimen surface (see Figure 5) demonstrate that the methodology truly reflects corrosion processes on the examined structural members.

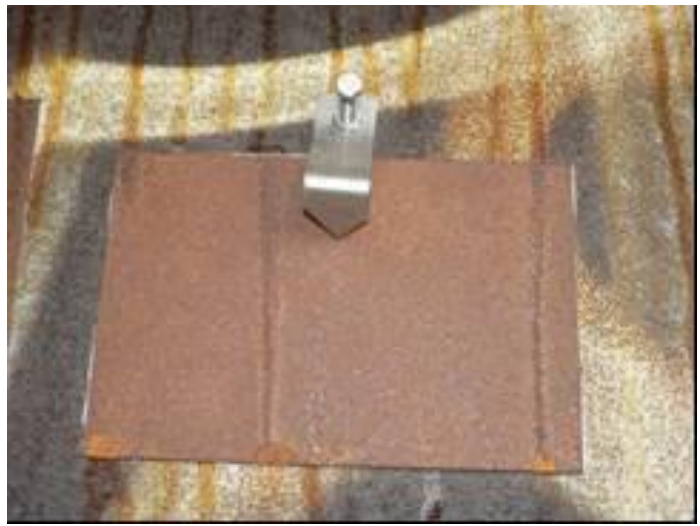

Figure 5 Specimens after one year exposure

The specimens of selected surface $\$ 3$ are installed on the external web of external (northern) main girder about $50 \mathrm{~mm}$ above the bottom flange. The surface is not affected by water leaking. Visual appearance of patina is typical for given surface, i.e. welldeveloped thicker and darker patina layer, see Figure 6.

The specimens were also installed on other typical surfaces of the bridge: external main girder - bottom surface of the upper flange (S4) and internal upper surface of the bottom flange (S8); external upper surface of the bottom flange (S5); bottom surface of the bottom flange (S6) and internal web 
of the internal main girder (S7). Thicknesses of corrosion products on the investigated surfaces were measured with a user friendly device based on the magneticinduction method [5] to find the dependence between corrosion rates and patina thickness [12]. The installation was financed by the Grant Agency of the Czech Republic (project 13-16124P).

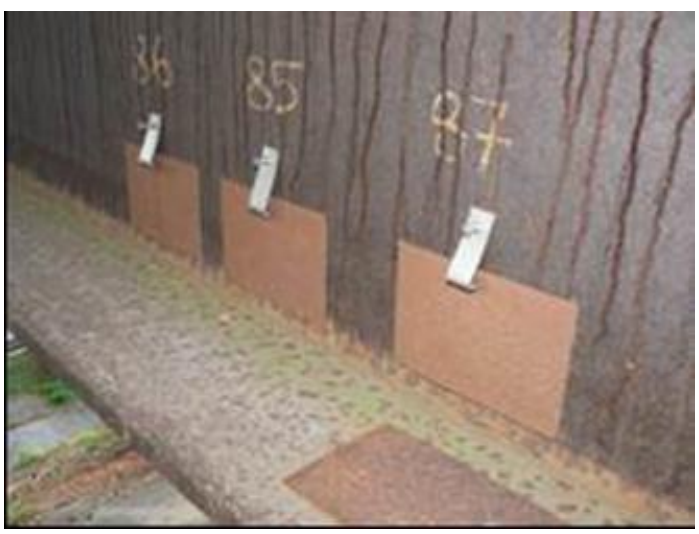

Figure 6 Darker patina layer about $50 \mathrm{~mm}$ above the bottom flange on external web of northern main girder

\subsection{SUMMARY RESULTS OF CORROSION TESTS}

The specimens were installed on the railway bridge in November 2012. One specimen from each examined surface was withdrawn after one year exposure. The following parameters were laboratory tested on the specimens: thickness of corrosion products (see Table 1), corrosion losses (see Table 2), comparison between corrosion thickness vs. corrosion losses (see Table 3) and X-Ray analysis of corrosion products chemical composition (see Table 4).

\subsection{CONCLUSIONS}

The highest corrosion losses were observed on upper surfaces of lower flanges. The corrosion loss on the external flange is significantly higher than that on the inner flange (the external flanges are generally more influenced by environmental effects). Darker strip of corrosion products on the web close to the bottom flange, see Fig. 6, is only a visual defect and it does not influence the corrosion resistance. The effect of surface orientation (northward vs. southward) is negligible. The results demonstrably show the expected correlation dependence between the measured corrosion losses and the thicknesses of corrosion products, see Figure 7. The correlation factor between both magnitudes is $\rho=0.98$. The measurement of patina thickness after one-year exposure may serve as a utility for realistic estimation of corrosion rates. The same dependence with high overall correlation factor $\rho=0.91$ was observed in results from corrosion tests on the road bridge in Ostrava [11] and over the Ostravice River in FrýdekMístek [12].

Table 1 Thickness of corrosion products after one-year of exposure (measured 20 values for each surface)

\begin{tabular}{ccccc}
\hline \multirow{2}{*}{ Surface ID } & \multicolumn{4}{c}{ thickness of corrosion products / $\boldsymbol{\mu m}$} \\
\cline { 2 - 5 } & Average & Max & Min & $\mathbf{S}_{\mathbf{x}}$ \\
\hline S1 & 25.4 & 43.0 & 12.0 & 9.3 \\
S2 & 30.5 & 78.0 & 7.0 & 16.6 \\
S3 & 29.1 & 64.0 & 9.0 & 15.4 \\
S4 & 39.4 & 74.0 & 17.0 & 16.5 \\
S5 & 87.4 & 154.0 & 45.0 & 31.1 \\
S6 & 31.0 & 16.0 & 50.0 & 9.4 \\
S7 & 23.7 & 52.0 & 7.0 & 12.4 \\
S8 & 54.1 & 104.0 & 26.0 & 18.3 \\
\hline
\end{tabular}


Table 2 Laboratory determined corrosion losses after one-year of exposure

\begin{tabular}{ccc}
\hline Surface ID & weight loss $/ \mathbf{g . m}^{-\mathbf{2}}$ & thickness loss $/ \boldsymbol{\mu m}$ \\
\hline S1 & 47.26 & 6.01 \\
S2 & 44.87 & 5.71 \\
S3 & 44.56 & 5.67 \\
S4 & 71.68 & 9.14 \\
S5 & 150.23 & 19.11 \\
S6 & 49.11 & 6.25 \\
S7 & 35.35 & 4.50 \\
S8 & 73.31 & 9.33 \\
\hline
\end{tabular}

Table 3 Comparison between average thickness of corrosion products and corrosion losses after one year of exposure

\begin{tabular}{ccc}
\hline Surface ID & $\begin{array}{c}\text { thickness of corrosion } \\
\text { products } / \boldsymbol{\mu m}\end{array}$ & thickness loss $/ \boldsymbol{\mu m}$ \\
\hline S1 & 25,4 & 6.01 \\
S2 & 30,5 & 5.71 \\
S3 & 29,1 & 5.67 \\
S4 & 39,4 & 9.14 \\
S5 & 87,4 & 19.11 \\
S6 & 31,0 & 6.25 \\
S7 & 23,7 & 4.50 \\
S8 & 54,1 & 9.33 \\
\hline
\end{tabular}

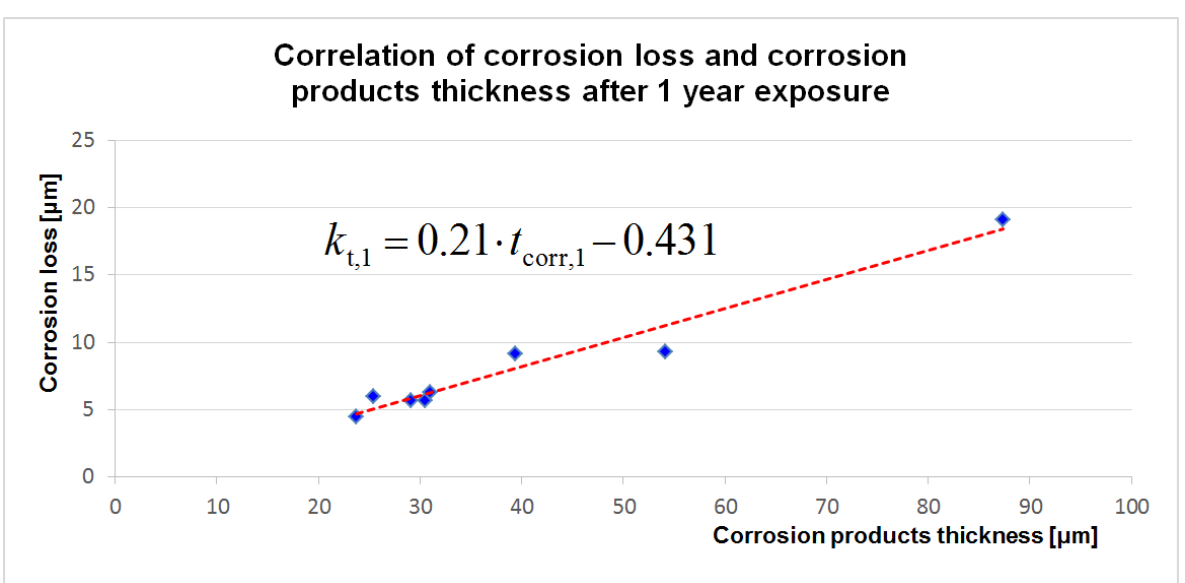

Figure 7 Graphic relationship between the measured corrosion losses and corrosion products thickness 
Table 4 Chemical analysis of corrosion products and protective ability index $[13,14]$ after one-year exposure

\begin{tabular}{clcc}
\hline Surface ID & \multicolumn{1}{c}{ Phase analysis - occurrence of minerals } & PAla & PAI $\boldsymbol{c}$ \\
\hline S1 & $\begin{array}{l}\text { domination of lepidocrocite, lower value of } \\
\text { goethite, traces of akaganeite } \\
\text { domination of lepidocrocite, low value of } \\
\text { goethite }\end{array}$ & 0.24 & 0.46 \\
S5 & $\begin{array}{l}\text { domination of lepidocrocite, lower value of } \\
\text { goethite, traces of akaganeite } \\
\text { domination of lepidocrocite, low value of } \\
\text { goethite }\end{array}$ & 0.34 & 0.60 \\
\hline
\end{tabular}

Note: $\quad$ Surface $S 1$ - northern external main girder - external web

Surface $\$ 2$ - southern external main girder - external web

Surface S3 - northern external main girder - external web $50 \mathrm{~mm}$ above the bottom flange

Surface $\$ 4$ - external main girder - bottom surface of the upper flange

Surface 55 - external upper surface of the bottom flange

Surface $\$ 6$ - bottom surface of the bottom flange

Surface 57 - internal web of the internal main girder

Surface $\$ 8$ - internal upper surface of the bottom flange

Chemical analysis of corrosion layers was performed and the PAI index was calculated as well. The corrosion products correspond to the initial period of patina development. Dominant phase of products was the mineral lepidocrocite $\mathrm{Y}$ - $\mathrm{FeO}(\mathrm{OH})$, secondary phase is comprised of goethite a-FeO $(\mathrm{OH})$. A higher proportion of the mineral akaganeite $\beta-\mathrm{FeO}(\mathrm{OH})$ was reflected on the value $P A I_{\beta}$ and observed only on surface $S 1$ and S5 (see Table 4).

\section{Acknowledgement}

This paper has been achieved with the financial support of the Ministry of Education, specifically by the Student Research Grant Competition of the Technical University of Ostrava under identification number SP2015/190.

\section{References}

[1] Albrecht, P. And Naeemi, A. H. 1984. Performance Of Weathering Steel In Bridges. NCHRP Rep. 272, National Cooperative Highway Research Program, Transportation Research Board, Washington, D. C.

[2] Albrecht, P. And Hall, T.T. 2003. Atmospheric Corrosion Resistance Of Structural Steel. Journal of Materials In Civil Engineering. 15(1): 2-24.
[3] Lebet, J. P. And Lang, T. P. 2001. Brücken Aus Wetterfestem Stahl. ICOM - Construction Métallique, EPFL, Lausanne, Switzerland.

[4] Technical Advisory T 5140.22 Uncoated Weathering Steel in Structures. 1989. Department Of Transportation Federal Highway Administration, USA.

[5] Morcillo, M. et al. 2014. Weathering Steels: From Empirical Development To Scientific Design. A Review. Corrosion Science. 83: 6-31.

[6] Morcillo, M. et al. 2013. Atmospheric Corrosion Data Of Weathering Steels. A Review. Corrosion Science. 77: 624.

[7] Fischer, M. 2004. Merkblatt 434: Wetterfester Baustahl. Düsseldorf: Stahl-Informations-Zentrum, Deutschland.

[8] BD 7/01. 2001. Weathering Steel for Highway Structures (British Standard). UK.

[9] Krivy, V., Marek, P. And Kreislova, K. 2013. Bestimmung Der Dickenzuschläge Für Wetterfesten Stahl Im Brückenbau. Stahlbau. 82(8): 583-588.

[10] Krivy, V. And Fabian, L. 2012. Calculation of Corrosion Losses On Weathering Steel Structures. Applied Mechanics and Materials. 188: 177-182.

[11] Urban, V., Krivy, V. And Fabian, L. 2014. Experimental Testing Of the Weathering Steel Road Bridge in Ostrava. Advanced Materials Research. 849: 228-233.

[12] Krivy, V., Urban, V. And Fabian, L. 2014. Experimental Investigation of Corrosion Processes On Weathering Steel Structures. Key Engineering Materials. 577-578: 397-400.

[13] Kamimura, T. et al. 2006. Composition And Protective Ability Of Rust Layer Formed On Weathering Steel Exposed To Various Environments. Corrosion Science. 48(9): 27992812.

[14] Hara, S. et al. 2007. Taxonomy For Protective Ability Of Rust Layer Using Its Composition Formed On Weathering Steel Bridge. Corrosion Science. 49(3): 1131-1142. 